\title{
Seohaeicola saemankumensis gen. nov., sp. nov., isolated from a tidal flat
}

Correspondence

Jung-Hoon Yoon

jhyoon@kribb.re.kr

\author{
Jung-Hoon Yoon, So-Jung Kang, Soo-Young Lee, Ki-Hoon Oh \\ and Tae-Kwang Oh
}

Korea Research Institute of Bioscience and Biotechnology (KRIBB), PO Box 115, Yusong, Taejon, Republic of Korea

\begin{abstract}
A Gram-negative, non-motile and rod-, oval- or coccoid-shaped bacterial strain, SD-15 ${ }^{\top}$, was isolated from a tidal flat of the Yellow Sea, Korea. The novel strain, which was phylogenetically closely related to the genera Phaeobacter, Leisingera and Marinovum, was studied using a polyphasic taxonomic approach. Strain SD-15 ${ }^{\top}$ grew optimally at $\mathrm{pH} 7.0-8.0$ and $30{ }^{\circ} \mathrm{C}$ in the presence of $2 \%(\mathrm{w} / \mathrm{v}) \mathrm{NaCl}$. It contained $\mathrm{Q}-10$ as the predominant ubiquinone and $\mathrm{C}_{18: 1} \omega 7 \mathrm{c}$ and 11-methyl $C_{18: 1} \omega 7 c$ as the major fatty acids. The major polar lipids were phosphatidylcholine, phosphatidylglycerol, phosphatidylethanolamine and an unidentified lipid. The DNA G+C content was $63.4 \mathrm{~mol} \%$. Strain SD $-15^{\top}$ exhibited the highest $16 \mathrm{~S}$ rRNA gene sequence similarity values (95.1-96.4\%) to the type strains of species of the genus Phaeobacter, Leisingera methylohalidivorans $\mathrm{MB}^{\top}$ and Marinovum algicola ATCC $51440^{\top}$. Strain SD-15 ${ }^{\top}$ could be differentiated from members of the genera Phaeobacter, Leisingera and Marinovum by differences in the contents of some fatty acids, by the absence of aminolipid and by differences in some phenotypic properties. On the basis of phenotypic, chemotaxonomic and phylogenetic data, strain SD-15 ${ }^{\top}$ represents a new genus and novel species, for which the name Seohaeicola saemankumensis gen. nov., sp. nov. is proposed. The type strain of the type species is Seohaeicola saemankumensis SD-15 ${ }^{\top}$ (=KCTC $22175^{\top}=$ CCUG $\left.55328^{\top}\right)$.
\end{abstract}

In the course of screening micro-organisms from a tidal flat of Saemankum in the Yellow Sea, Korea, using diluted marine agar 2216 (Difco), many novel bacterial strains that belong to the class Alphaproteobacteria have been isolated. One of these isolates, strain SD-15 ${ }^{\mathrm{T}}$, which was most phylogenetically related to the genera Phaeobacter, Leisingera and Marinovum, is described in this study. The genus Phaeobacter was created by Martens et al. (2006) through the reclassification of Roseobacter gallaeciensis and the description of one novel species, Phaeobacter inhibens. Two further species of the genus have been described recently, Phaeobacter daeponensis (Yoon et al., 2007) and Phaeobacter caeruleus (Vandecandelaere et al., 2009). The genus Marinovum was created by the reclassification of Ruegeria algicola (previously Roseobacter algicola) (Martens et al., 2006). The genus Leisingera was proposed by Schaefer et al. (2002) with a single species, Leisingera methylohalidivorans. The aim of the present study was to determine the exact taxonomic position of strain SD-15 by using a polyphasic approach that included determination of phenotypic and chemotaxonomic properties and a

Abbreviations: ASW, artificial seawater; BChl a, bacteriochlorophyll a; TEM, transmission electron microscope.

The GenBank/EMBL/DDBJ accession number for the $16 \mathrm{~S}$ rRNA gene sequence of strain SD-15 ${ }^{\top}$ is EU221274. detailed phylogenetic investigation based on 16S rRNA gene sequences.

Strain SD- $15^{\mathrm{T}}$ was isolated by means of the standard dilution plating technique at $25{ }^{\circ} \mathrm{C}$ on $10 \times$ diluted marine agar 2216 (MA; Difco). Growth on $10 \times$ diluted MA, $5 \times$ diluted MA, $2 \times$ diluted MA and full strength MA was measured at $30{ }^{\circ} \mathrm{C}$. The morphological, physiological and biochemical characteristics of strain SD- $15^{\mathrm{T}}$ were investigated using routine cultivation on MA at $30{ }^{\circ} \mathrm{C}$. Cell morphology was examined by light microscopy (E600; Nikon) and transmission electron microscopy (TEM). Flagellation was determined by using a Philips CM-20 TEM with cells from exponentially growing cultures. For this purpose, the cells were negatively stained with $1 \%$ $(\mathrm{w} / \mathrm{v})$ phosphotungstic acid and the grids were examined after being air-dried. The Gram-reaction was determined by using the bioMérieux Gram stain kit according to the manufacturer's instructions.

Growth under anaerobic conditions was determined after incubation in a Forma anaerobic chamber on MA and MA supplemented with potassium nitrate $(0.1 \%$, w/v $)$, both of which had been prepared anaerobically using nitrogen. Growth in the absence of $\mathrm{NaCl}$ was investigated using trypticase soy broth prepared according to the formula of the Difco medium except that $\mathrm{NaCl}$ was excluded from the 
medium formula. Growth at various $\mathrm{NaCl}$ concentrations [0.5\% (w/v) and $1.0-10.0 \%(\mathrm{w} / \mathrm{v})$, in increments of $1.0 \%)]$ was investigated in marine broth 2216 (MB; Difco) or trypticase soy broth (Difco). Growth at various temperatures $(4,10,15,20,22,25,28,30,35$ and 37 and from 40 to $45{ }^{\circ} \mathrm{C}$ in $1{ }^{\circ} \mathrm{C}$ increments) was measured on MA. The $\mathrm{pH}$ range for growth was determined in $\mathrm{MB}$ that was adjusted to various $\mathrm{pH}$ values ( $\mathrm{pH} 4.5-9.5$ in increments of $0.5 \mathrm{pH}$ units). Catalase and oxidase activities and hydrolysis of casein, starch and Tweens 20, 40, 60 and 80 were determined as described by Cowan \& Steel (1965). Hydrolysis of hypoxanthine, tyrosine and xanthine was tested on MA using the substrate concentrations described by Cowan \& Steel (1965). Hydrolysis of aesculin, gelatin and urea and nitrate reduction were investigated as described previously (Lányí, 1987) with a modification that artificial seawater (ASW) was used for the preparation of media. The ASW contained $\left(1^{-1}\right.$ distilled water) $23.6 \mathrm{~g}$ $\mathrm{NaCl}, \quad 0.64 \mathrm{~g} \quad \mathrm{KCl}, \quad 4.53 \mathrm{~g} \quad \mathrm{MgCl}_{2} .6 \mathrm{H}_{2} \mathrm{O}, \quad 5.94 \mathrm{~g}$ $\mathrm{MgSO}_{4} \cdot 7 \mathrm{H}_{2} \mathrm{O}$ and $1.3 \mathrm{~g} \mathrm{CaCl} \cdot 2 \mathrm{H}_{2} \mathrm{O}$ (Bruns et al., 2001). $\mathrm{H}_{2} \mathrm{~S}$ production was tested as described previously (Bruns et al., 2001).

For in vivo pigment-absorption spectrum analysis, strain SD- $15^{\mathrm{T}}$ was cultivated aerobically in the dark at $30{ }^{\circ} \mathrm{C}$ in $\mathrm{MB}$. The cultures were washed twice by centrifugation using a MOPS buffer $(0.01 \mathrm{M} \mathrm{MOPS} / \mathrm{NaOH}, 0.1 \mathrm{M} \mathrm{KCl}$, $\left.0.001 \mathrm{M} \mathrm{MgCl}_{2}, \mathrm{pH} 7.5\right)$ and disrupted by sonication with a Branson Sonifier 450. After removal of cell debris by centrifugation, the absorption spectrum of the supernatant was examined on a spectrophotometer (DU800; Beckman Coulter).

Susceptibility to antibiotics was investigated on MA plates by using antibiotic discs with the following concentrations; polymyxin B (100 U), streptomycin $(50 \mu \mathrm{g})$, penicillin $\mathrm{G}$ (20 U), chloramphenicol $(100 \mu \mathrm{g})$, ampicillin $(10 \mu \mathrm{g})$, cephalothin $(30 \mu \mathrm{g})$, gentamicin $(30 \mu \mathrm{g})$, novobiocin $(5 \mu \mathrm{g})$, tetracycline $(30 \mu \mathrm{g})$, kanamycin $(30 \mu \mathrm{g})$, lincomycin $(15 \mu \mathrm{g})$, oleandomycin $(15 \mu \mathrm{g})$, neomycin $(30 \mu \mathrm{g})$ and carbenicillin $(100 \mu \mathrm{g})$. Utilization of various substrates for growth was tested on basal medium agar $[50 \mathrm{mM}$ Tris/ $\mathrm{HCl}$, pH 7.5; $190 \mathrm{mM} \quad \mathrm{NH}_{4} \mathrm{Cl}, \quad 0.33 \mathrm{mM} \quad \mathrm{K}_{2} \mathrm{HPO}_{4} .3 \mathrm{H}_{2} \mathrm{O}$, $0.1 \mathrm{mM} \mathrm{FeSO}{ }_{4} \cdot 7 \mathrm{H}_{2} \mathrm{O}$ and $1.5 \%$ Noble agar (Difco) in half-strength ASW; Baumann \& Baumann, 1981] supplemented with $0.01 \%$ yeast extract. The ASW contained $\left(1^{-1}\right.$ distilled water) $24 \mathrm{~g} \mathrm{NaCl}, 5.1 \mathrm{~g} \mathrm{MgCl}_{2}, 4 \mathrm{~g} \mathrm{Na}_{2} \mathrm{SO}_{4}, 1.1 \mathrm{~g}$ $\mathrm{CaCl}_{2}, 0.7 \mathrm{~g} \mathrm{KCl}, 0.2 \mathrm{~g} \mathrm{NaHCO}_{3}, 0.1 \mathrm{~g} \mathrm{KBr}, 0.027 \mathrm{~g}$ $\mathrm{H}_{3} \mathrm{BO}_{3}, \quad 0.024 \mathrm{~g} \mathrm{SrCl}_{2}$ and $0.003 \mathrm{~g} \mathrm{NaF}$ (Lyman \& Fleming, 1940). The carbon sources were added at a concentration of $0.2 \%(\mathrm{w} / \mathrm{v})$ after sterilization by filtration. Enzyme activities were determined by using the API ZYM system (bioMérieux).

Cell biomass for DNA extraction and for the analyses of isoprenoid quinones and polar lipids was obtained from cultures grown in $\mathrm{MB}$ at $30{ }^{\circ} \mathrm{C}$. Chromosomal DNA was isolated and purified according to the method described by Yoon et al. (1996), with the exception that RNase T1 was used in combination with RNase A to minimize the contamination of RNA. The 16S rRNA gene was amplified by PCR using two universal primers, 5'-GAGTTTGATCCTGGCTCAG-3' and ' ${ }^{\prime}$-AGAAAGGAGGTGATCCAGCC-3', as described previously (Yoon et al., 1998). Sequencing of the amplified 16S rRNA gene and phylogenetic analysis were performed as described by Yoon et al. (2003). Isoprenoid quinones were analysed as described by Komagata \& Suzuki (1987) using reversed-phase HPLC. For cellular fatty acid analysis, cell mass of strain SD- $15^{\mathrm{T}}$ was harvested from MA plates after cultivation for 3 days at $30{ }^{\circ} \mathrm{C}$. The fatty acids were extracted and fatty acid methyl esters were prepared according to the standard protocol of the MIDI/Hewlett Packard Microbial Identification System (Sasser, 1990). Polar lipids were extracted according to the procedures described by Minnikin et al. (1984) and identified by two-dimensional TLC followed by spraying with appropriate detection reagents (Minnikin et al., 1984; Komagata \& Suzuki, 1987). The presence of phosphatidylcholine was identified by spraying with Dragendorffs reagent (Sigma). The DNA $\mathrm{G}+\mathrm{C}$ content was determined by the method of Tamaoka \& Komagata (1984) with a modification that DNA was hydrolysed using nuclease P1 (Sigma) and the resultant nucleotides were analysed by reversed-phase HPLC.

The morphological, cultural, physiological and biochemical characteristics of strain SD- $15^{\mathrm{T}}$ are given in the genus and species descriptions (see below) or are shown in Table 1 . Strain SD- $15^{\mathrm{T}}$ did not produce bacteriochlorophyll a $(\mathrm{BChl} a)$ aerobically in the dark. The sonicated in vivo cell extracts of strain $\mathrm{SD}-15^{\mathrm{T}}$ showed no absorption maximum. The almost complete $16 \mathrm{~S}$ rRNA gene sequence of strain SD- $15^{\mathrm{T}}$ determined in this study comprised 1422 nt, representing approximately $96 \%$ of the Escherichia coli $16 \mathrm{~S}$ rRNA gene sequence. In the phylogenetic tree based on the neighbour-joining algorithm, strain $\mathrm{SD}-15^{\mathrm{T}}$ joined the clade comprising the genera Phaeobacter, Leisingera and Marinovum with a bootstrap resampling value of $80.6 \%$ (Fig. 1). Strain SD-15 ${ }^{\mathrm{T}}$ exhibited $16 \mathrm{~S}$ rRNA gene sequence similarity values of $95.1-96.4 \%$ to the type strains of four species of the genus Phaeobacter, $96.0 \%$ to Leisingera methylohalidivorans $\mathrm{MB}^{\mathrm{T}}$, $95.5 \%$ to Marinovum algicola ATCC $51440^{\mathrm{T}}$ and below $95.2 \%$ to the other species used in the phylogenetic analysis.

The predominant isoprenoid quinone detected in strain SD- $15^{\mathrm{T}}$ was ubiquinone-10 (Q-10) at a peak area ratio of approximately $94 \%$. The cellular fatty acid profile of strain $\mathrm{SD}-15^{\mathrm{T}}$ is shown in Table 2, together with those of phylogenetically related genera analysed previously. The major fatty acids ( $>10 \%$ of total fatty acids) detected in strain SD- $15^{\mathrm{T}}$ were $\mathrm{C}_{18: 1} \omega 7 c$ and 11-methyl $\mathrm{C}_{18: 1} \omega 7 c$. The major polar lipids found in strain $\mathrm{SD}-15^{\mathrm{T}}$ were phosphatidylcholine, phosphatidylglycerol, phosphatidylethanolamine and an unidentified lipid; minor amounts of phospholipids were also present. The DNA G $+\mathrm{C}$ content of strain $\mathrm{SD}-15^{\mathrm{T}}$ was $63.4 \mathrm{~mol} \%$. 
Table 1. Differential phenotypic characteristics of strain SD-15 ${ }^{\top}$ and the genera Phaeobacter, Leisingera and Marinovum

Taxa: 1, strain SD-15 ; 2, Phaeobacter (data from Ruiz-Ponte et al., 1998; Martens et al., 2006; Yoon et al., 2007; Vandecandelaere et al., 2009); 3, Leisingera (Schaefer et al., 2002; Martens et al., 2006; Yoon et al., 2007); 4, Marinovum (Lafay et al., 1995; Ruiz-Ponte et al., 1998; Martens et al., 2006; Yoon et al., 2007). +, Positive; -, negative; W, weakly positive; ND, not determined or not described; V, variable reaction; PC, phosphatidylcholine; PG, phosphatidylglycerol; PE, phosphatidylethanolamine; PL, unidentified phospholipid; AL, aminolipid; L, unidentified lipid. Data in parentheses are for the type strain. All taxa are positive for catalase and oxidase activities. All taxa are negative for Gram-staining, hydrolysis of Tween 80 and presence of bacteriochlorophyll $a^{*}$.

\begin{tabular}{|c|c|c|c|c|}
\hline Characteristic & 1 & 2 & 3 & 4 \\
\hline Colony colour & Pale yellow & No pigment, brown or blue & No pigment & Beige/pinkish beige \\
\hline $4{ }^{\circ} \mathrm{C}$ & + & $\mathrm{v}$ & + & - \\
\hline $37^{\circ} \mathrm{C}$ & + & $\mathrm{v}$ & - & + \\
\hline Nitrate reduction & + & $\mathrm{v}$ & - & - \\
\hline \multicolumn{5}{|l|}{ Hydrolysis of: } \\
\hline Gelatin & - & - & - & + \\
\hline Starch & - & - & + & $\mathrm{w}$ \\
\hline \multicolumn{5}{|l|}{ Utilization of: } \\
\hline Acetate & + & $\mathrm{v}$ & - & $\mathrm{V}(+)$ \\
\hline L-Arabinose & - & - or $\mathrm{ND}$ & - & $+\dagger$ \\
\hline D-Glucose & - & $\mathrm{v}$ & - & + \\
\hline L-Glutamate & - & $\mathrm{v}$ & - & + \\
\hline L-Malate & $\mathrm{w}$ & $\mathrm{v}$ & - & + \\
\hline Maltose & - & $\mathrm{v}$ & - & + \\
\hline D-Mannose & $\mathrm{w}$ & $\mathrm{V}$ & - & - \\
\hline Pyruvate & - & + or $\mathrm{ND}$ & - & + \\
\hline Succinate & $\mathrm{W}$ & + or $\mathrm{ND}$ & - & - \\
\hline Sucrose & - & V & - & + \\
\hline Trehalose & - & $\mathrm{v}$ & - & + \\
\hline D-Xylose & - & $\mathrm{v}$ & - & - \\
\hline \multicolumn{5}{|l|}{ Susceptibility to: } \\
\hline Polar lipids & PC, PG, PE, L, PLs & PC, PG, PE, Ls, AL, PL & PG, PE, PL, Ls, AL & PC, PG, PE, L, AL, PL \\
\hline DNA G $+C$ mol $\%$ & 63.4 & $55.7-64.9$ & 60.5 & $(60)$ \\
\hline
\end{tabular}

${ }^{\star}$ Data for Phaeobacter caeruleus were not determined.

$\dagger$ Data for the type strain of Marinovum algicola taken from Labrenz et al. (1999).

$\ddagger$ Data for P. gallaeciensis taken from Martens et al. (2006).

The phylogenetic analyses based on $16 \mathrm{~S}$ rRNA gene sequences indicated that strain $\mathrm{SD}-15^{\mathrm{T}}$ did not fall within the radiation encompassed by a recognized genus but formed a distinct evolutionary lineage within the class Alphaproteobacteria (Fig. 1). The differences in content of some fatty acids, particularly hydroxy fatty acids and cyclo
$\mathrm{C}_{19: 0} \omega 8 c$, distinguished strain $\mathrm{SD}-15^{\mathrm{T}}$ from the phylogenetically related genera, Phaeobacter, Leisingera and Marinovum (Table 2). Strain SD- $15^{\mathrm{T}}$ differed from the genera Phaeobacter, Leisingera and Marinovum in that aminolipid was absent (Table 1). Strain SD- $15^{\mathrm{T}}$ could be differentiated from the three phylogenetically related 


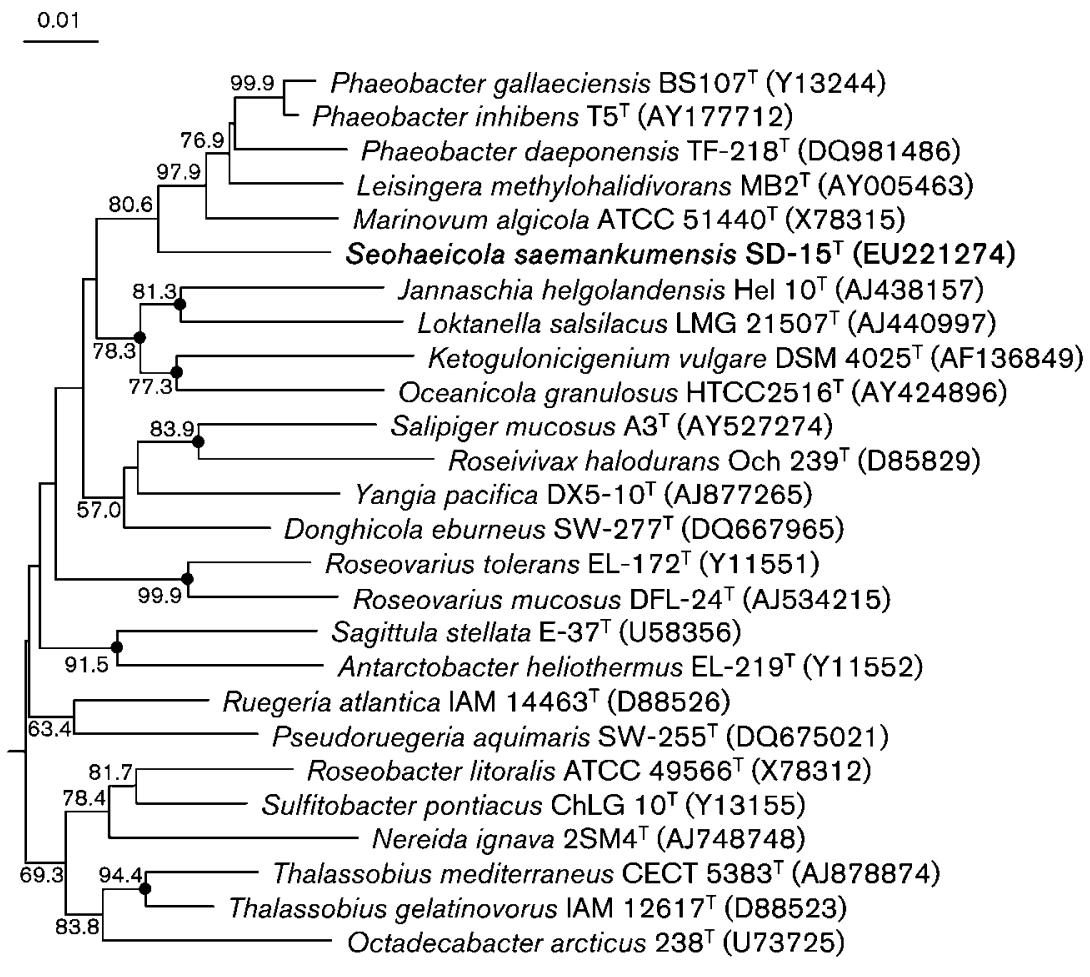

Fig. 1. Neighbour-joining phylogenetic tree based on 16S rRNA gene sequences showing the positions of strain $S D-15^{\top}$ and other related taxa. Bootstrap values (expressed as percentages of 1000 replications) of $>50 \%$ are shown at branch points. Filled circles indicate that the corresponding nodes were also recovered in the trees generated with the maximum-likelihood and maximum-parsimony algorithms. Escherichia coli ATCC $11775^{\top}$ was used as an outgroup. Bar, 0.01 substitutions per nucleotide position. genera by differences in some phenotypic properties as listed in Table 1. The phylogenetic data and differential chemotaxonomic and phenotypic properties suggest that strain SD-15 ${ }^{\mathrm{T}}$ constitutes a new genus and species within the class Alphaproteobacteria, for which the name Seohaeicola saemankumensis gen. nov., sp. nov. is proposed.

\section{Description of Seohaeicola gen. nov.}

Seohaeicola [Se.o.hae.i'co.la. N.L. n. Seohaeum Seohae, the Korean name of the Yellow Sea in Korea; L. suff. -cola (from L. n. incola) a dweller, inhabitant; N.L. masc. n. Seohaeicola a dweller of the Yellow Sea in Korea].

Cells are Gram-negative, non-motile and rod-, oval- or coccoid-shaped $(0.7-1.8 \times 1.0-10.0 \mu \mathrm{m})$. The predominant ubiquinone is Q-10. The major fatty acids are $\mathrm{C}_{18: 1} \omega 7 c$ and 11-methyl $\mathrm{C}_{18: 1} \omega 7 \mathrm{c}$. The major polar lipids are phosphatidylcholine, phosphatidylglycerol, phosphatidylethanolamine and an unidentified lipid. The type species is Seohaeicola saemankumensis.

\section{Description of Seohaeicola saemankumensis sp. nov.}

Seohaeicola saemankumensis (sae.man.kum.en'sis. N.L. masc. adj. saemankumensis of Saemankum, region from where the organisms were isolated).

The description is as for the genus with the following additional properties. Colonies on MA are circular, raised, smooth, pale yellow in colour and 1.0-1.5 $\mathrm{mm}$ in diameter after 7 days incubation at $30{ }^{\circ} \mathrm{C}$. Growth occurs at 4 and
$40{ }^{\circ} \mathrm{C}$, but not at $41{ }^{\circ} \mathrm{C}$. Optimal $\mathrm{pH}$ for growth is between 7.0 and 8.0; growth occurs at $\mathrm{pH} 5.5$, but not at $\mathrm{pH}$ 5.0. Optimal $\mathrm{NaCl}$ concentration for growth is $2 \%(\mathrm{w} / \mathrm{v})$; growth occurs in the presence of $7 \%(\mathrm{w} / \mathrm{v}) \mathrm{NaCl}$, but not in the absence of $\mathrm{NaCl}$ or in the presence of more than $8 \%$ $(\mathrm{w} / \mathrm{v}) \mathrm{NaCl}$. Anaerobic growth occurs on MA and on MA supplemented with nitrate. Urease-negative. Tweens 20, 40 and 60, aesculin, casein, hypoxanthine, L-tyrosine and xanthine are not hydrolysed. $\mathrm{H}_{2} \mathrm{~S}$ is not produced. Benzoate, formate and salicin are not utilized as sole carbon and energy sources. Susceptible to ampicillin, cephalothin, tetracycline, carbenicillin and oleandomycin, but not to lincomycin or polymyxin B. In assays with the API ZYM system, esterase (C4), esterase lipase (C8) and leucine arylamidase are present, but alkaline phosphatase, lipase (C14), valine arylamidase, cystine arylamidase, trypsin, $\alpha$-chymotrypsin, acid phosphatase, naphthol-ASBI-phosphohydrolase, $\alpha$-galactosidase, $\beta$-galactosidase, $\beta$ glucuronidase, $\alpha$-glucosidase, $\beta$-glucosidase, $N$-acetyl- $\beta$ glucosaminidase, $\alpha$-mannosidase and $\alpha$-fucosidase are absent. The predominant ubiquinone is Q-10. The major fatty acids $\left(>10 \%\right.$ of total fatty acids) are $\mathrm{C}_{18: 1} \omega 7 c$ and 11-methyl $\mathrm{C}_{18: 1} \omega 7 c$. Major polar lipids are phosphatidylcholine, phosphatidylglycerol, phosphatidylethanolamine and an unidentified lipid. Other phenotypic characteristics are given in Table 1.

The type strain, SD- $15^{\mathrm{T}}\left(=\right.$ KCTC $22175^{\mathrm{T}}=$ CCUG $55328^{\mathrm{T}}$ ), was isolated from a tidal flat of Saemankum in the Yellow Sea, Korea. The DNA G $+\mathrm{C}$ content of the type strain is $63.4 \mathrm{~mol} \%$ (determined by HPLC). 
Table 2. Cellular fatty acid contents (\%) of strain SD $-15^{\top}$ and the genera Phaeobacter, Leisingera and Marinovum

Taxa: 1, strain SD-15 ${ }^{\mathrm{T}}$; 2, Phaeobacter (data from Yoon et al., 2007; Vandecandelaere et al., 2009); 3, Leisingera methylohalidivorans DSM $14336^{\mathrm{T}}$ (Yoon et al., 2007); 4, Marinovum algicola DSM $10251^{\mathrm{T}}$ (Yoon et al., 2007). Fatty acids that represented $<0.5 \%$ in all strains, except Phaeobacter caeruleus, were omitted. -, Not detected.

\begin{tabular}{|c|c|c|c|c|}
\hline Fatty acid & 1 & 2 & 3 & 4 \\
\hline \multicolumn{5}{|c|}{ Straight-chain fatty acids: } \\
\hline $\mathrm{C}_{12: 0}$ & - & $0.4-1.2^{*}$ & 0.6 & - \\
\hline $\mathrm{C}_{16: 0}$ & 8.0 & $3.7-8.6$ & 3.2 & 2.5 \\
\hline $\mathrm{C}_{17: 0}$ & - & $0.2-0.6^{\star}$ & 0.1 & 0.3 \\
\hline $\mathrm{C}_{18: 0}$ & - & $0.9-2.4$ & 0.5 & 2.5 \\
\hline \multicolumn{5}{|c|}{ Unsaturated fatty acids: } \\
\hline $\mathrm{C}_{17: 1} \omega 8 c$ & - & $-*$ & 0.2 & 0.8 \\
\hline $\mathrm{C}_{18: 1} \omega 7 c$ & 68.0 & $57.7-82.3$ & 77.5 & 81.0 \\
\hline \multicolumn{5}{|l|}{ Hydroxy fatty acids: } \\
\hline $\mathrm{C}_{10: 0} 3-\mathrm{OH}$ & - & $1.7-3.2$ & 1.8 & 1.1 \\
\hline $\mathrm{C}_{12: 0} 3-\mathrm{OH}$ & - & $1.6-2.6$ & 2.1 & 1.2 \\
\hline $\mathrm{C}_{16: 0} 2-\mathrm{OH}$ & - & $2.0-5.6$ & 4.7 & - \\
\hline $\mathrm{C}_{18: 1} 2-\mathrm{OH}$ & - & $-*$ & 0.6 & - \\
\hline 11-methyl $\mathrm{C}_{18: 1} \omega 7 c$ & 12.9 & $0.9-16.6$ & 4.7 & 9.6 \\
\hline Cyclo $\mathrm{C}_{19: 0} \omega 8 \mathrm{c}$ & 5.4 & $-*$ & - & - \\
\hline Summed feature $3 \dagger$ & - & $0.2-0.5^{\star}$ & 0.5 & 0.2 \\
\hline $\begin{array}{l}\text { Unknown fatty acid } \\
\text { (ECL 11.799) }\end{array}$ & 5.7 & $2.3-3.3$ & 3.1 & - \\
\hline
\end{tabular}

${ }^{\star}$ Data for Phaeobacter caeruleus $<1.0 \%$ or not detected.

$\dagger$ Summed features represent groups of two or three fatty acids which could not be separated by GLC with the MIDI system. Summed feature 3 contained $\mathrm{C}_{16: 1} \omega 7 c$ and/or iso- $\mathrm{C}_{15: 0} 2-\mathrm{OH}$.

\section{Acknowledgements}

This work was supported by the 21C Frontier program of Microbial Genomics and Applications (grant MG05-0401-2-0) and the program of Collection, Management and Utilization of Biological Resources from the Ministry of Education, Science and Technology (MEST) of the Republic of Korea.

\section{References}

Baumann, P. \& Baumann, L. (1981). The marine Gram-negative eubacteria: genera Photobacterium, Beneckea, Alteromonas, Pseudomonas, and Alcaligenes. In The Prokaryotes, pp. 1302-1331. Edited by M. P. Starr, H. Stolp, H. G. Trüper, A. Balows \& H. G. Schlegel. Berlin: Springer-Verlag.

Bruns, A., Rohde, M. \& Berthe-Corti, L. (2001). Muricauda ruestringensis gen. nov., sp. nov., a facultatively anaerobic, appendaged bacterium from German North Sea intertidal sediment. Int $J$ Syst Evol Microbiol 51, 1997-2006.

Cowan, S. T. \& Steel, K. J. (1965). Manual for the Identification of Medical Bacteria. London: Cambridge University Press.
Komagata, K. \& Suzuki, K. (1987). Lipid and cell-wall analysis in bacterial systematics. Methods Microbiol 19, 161-207.

Labrenz, M., Collins, M. D., Lawson, P. A., Tindall, B. J., Schumann, P. \& Hirsch, P. (1999). Roseovarius tolerans gen. nov., sp. nov., a budding bacterium with variable bacteriochlorophyll a production from hypersaline Ekho Lake. Int J Syst Bacteriol 49, 137-147.

Lafay, B., Ruimy, R., de Traubenberg, C. R., Breittmayer, V., Gauthier, M. J. \& Christen, R. (1995). Roseobacter algicola sp. nov., a new marine bacterium isolated from the phycosphere of the toxinproducing dinoflagellate Prorocentrum lima. Int J Syst Bacteriol 45, 290-296.

Lányí, B. (1987). Classical and rapid identification methods for medically important bacteria. Methods Microbiol 19, 1-67.

Lyman, J. \& Fleming, R. H. (1940). Composition of sea water. J Mar Res 3, 134-146.

Martens, T., Heidorn, T., Pukall, R., Simon, M., Tindall, B. J. \& Brinkhoff, T. (2006). Reclassification of Roseobacter gallaeciensis RuizPonte et al. 1998 as Phaeobacter gallaeciensis gen. nov., comb. nov., description of Phaeobacter inhibens sp. nov., reclassification of Ruegeria algicola (Lafay et al. 1995) Uchino et al. 1998 as Marinovum algicola gen. nov., comb. nov., and emended descriptions of the genera Roseobacter, Ruegeria and Leisingera. Int J Syst Evol Microbiol 56, 1293-1304.

Minnikin, D. E., O'Donnell, A. G., Goodfellow, M., Alderson, G., Athalye, M., Schaal, A. \& Parlett, J. H. (1984). An integrated procedure for the extraction of bacterial isoprenoid quinones and polar lipids. J Microbiol Methods 2, 233-241.

Ruiz-Ponte, C., Cilia, V., Lambert, C. \& Nicolas, J. L. (1998). Roseobacter gallaeciensis sp. nov., a new marine bacterium isolated from rearings and collectors of the scallop Pecten maximus. Int J Syst Bacteriol 48, 537-542.

Sasser, M. (1990). Identification of bacteria by gas chromatography of cellular fatty acids, MIDI Technical Note 101. Newark, DE: MIDI Inc.

Schaefer, J. K., Goodwin, K. D., McDonald, I. R., Murrell, J. C. \& Oremland, R. S. (2002). Leisingera methylohalidivorans gen. nov., sp. nov., a marine methylotroph that grows on methyl bromide. Int J Syst Evol Microbiol 52, 851-859.

Tamaoka, J. \& Komagata, K. (1984). Determination of DNA base composition by reversed-phase high-performance liquid chromatography. FEMS Microbiol Lett 25, 125-128.

Vandecandelaere, I., Segaert, E., Mollica, A., Faimali, M. \& Vandamme, P. (2009). Phaeobacter caeruleus sp. nov., a blue-coloured colony forming bacterium isolated from a marine electroactive biofilm. Int J Syst Evol Microbiol 59, 1209-1214.

Yoon, J.-H., Kim, H., Kim, S.-B., Kim, H.-J., Kim, W. Y., Lee, S. T., Goodfellow, M. \& Park, Y.-H. (1996). Identification of Saccharomonospora strains by the use of genomic DNA fragments and rRNA gene probes. Int J Syst Bacteriol 46, 502-505.

Yoon, J.-H., Lee, S. T. \& Park, Y.-H. (1998). Inter- and intraspecific phylogenetic analysis of the genus Nocardioides and related taxa based on 16S rRNA gene sequences. Int J Syst Bacteriol 48, 187-194.

Yoon, J.-H., Kang, K. H. \& Park, Y.-H. (2003). Psychrobacter jeotgali sp. nov., isolated from jeotgal, a traditional Korean fermented seafood. Int J Syst Evol Microbiol 53, 449-454.

Yoon, J.-H., Kang, S.-J., Lee, S.-Y. \& Oh, T.-K. (2007). Phaeobacter daeponensis sp. nov., isolated from a tidal flat of the Yellow Sea in Korea. Int J Syst Evol Microbiol 57, 856-861. 